\title{
APLIKASI SERBUK WORTEL SEBAGAI SUMBER B-KAROTEN ALAMI PADA PRODUK MI INSTAN
}

\author{
(Application of carrot powder as natural B-carotene sources on instant noodle)
}

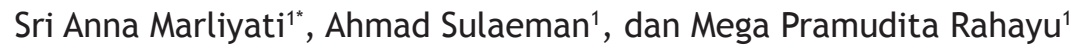 \\ 1Departemen Gizi Masyarakat, FEMA-IPB
}

\begin{abstract}
The objective of this research was to study the use of carrot powder as a source of natural B-carotene in instant noodle. Four formulas were developed based on carrot powder level added into the formula $10 \%$, $10 \%, 15 \%$, and $20 \%)$. The carrot instant noodle was evaluated for sensory properties by 30 panelists. The best formula was analyzed for chemical properties, including proximate composition, dietary fibre, and $B$-carotene. The physical properties were analyzed in color, cooking time, elasticity, and water holding capacity. The experimental design applied terms of Complete Randomized Design. The result showed that instant noodle with $15 \%$ carrot powder was the best formula of carrot instant noodle. No significant difference in acceptance between this formula and commercial instant noodles. Product was composed of moisture content $7.75 \%(w b)$, ash $1.59 \%(d . b)$, protein $12.82 \%(d . b)$, fat $1.41 \%(d . b)$, carbohydrate $84.18 \%(d . b)$ and B-carotene $2390 \mu \mathrm{g} / 100 \mathrm{~g}$ (199 RE or 99.5 RAE/serving size). Carrot instant noodle had physical properties as cooking time was 3.5 minutes, the color was yellow-redish, elasticity properties was $162.22 \%$, and water holding capacity was $143.89 \%$. This noodle contribute above $15 \%$ RDA of vitamin A for the children aged $4-5$ years.
\end{abstract}

Key words: B-carotene, carrot powder, instant noodle

\begin{abstract}
ABSTRAK
Tujuan penelitian ini adalah untuk mempelajari penggunaan serbuk wortel sebagai sumber beta karoten alami dalam mi instan. Empat formula dikembangkan berdasarkan jumlah serbuk wortel yang ditambahkan $(0 \%$, $10 \%, 15 \%$, dan $20 \%$ ). Mi instan wortel dievaluasi sifat organoleptiknya oleh 30 orang panelis. Formula terbaik dianalisis sifat-sifat kimianya meliputi komposisi, serat pangan, dan beta karoten, sedangkan sifat-sifat fisik yang dianalisis adalah warna, waktu masak, elastisitas, dan daya serap air. Rancangan percobaan yang digunakan adalah Rancangan Acak Lengkap. Hasil penelitian menunjukkan bahwa mi instan dengan penambahan 15\% serbuk wortel merupakan formula terbaik. Tidak ada perbedaan yang nyata dalam penerimaan antara mi instan formula ini dengan mi instan komersial. Produk mi instan ini mengandung air sebesar $7.75 \%$ (bb), abu 1.59\% (bk), protein 12.82\% (bk), lemak 1.41\% (bk), karbohidrat 84.18\% (bk) dan karoten $2390 \mu \mathrm{g} / 100 \mathrm{~g}$ (199 $\mathrm{RE}$ atau 99.5 RAE/takaran saji). Mi instan wortel mempunyai sifat-sifat fisik seperti waktu masak 3.5 menit, warna kuning kemerahan, elastisitas $162.22 \%$, dan daya serap air $143.89 \%$. Mi ini berkontribusi sebesar $15 \%$ terhadap Angka Kecukupan Gizi vitamin A untuk anak usia 4-5 tahun.
\end{abstract}

Kata kunci: B-karoten, mi instan, serbuk wortel

"Korespondensi: Departemen Gizi Masyarakat, Fakultas Ekologi Manusia (FEMA), Institut Pertanian Bogor, Jl. Raya Darmaga, 16680. Tel: 0251 - 8621363, Fax: 0251 - 8622276; Email: anna_marliyati@yahoo.com 


\section{PENDAHULUAN}

Kurang Vitamin A (KVA) merupakan penyebab utama kesakitan dan kematian anak usia prasekolah di negara berkembang (Maqsood et al. 2004). Lebih dari 127 juta anak di dunia mengalami ketidakcukupan asupan Vitamin A (West 2002). Hasil studi masalah gizi mikro di Indonesia pada tahun 2006 menunjukkan bahwa kadar serum vitamin A balita rata-rata hanya $11 \mu \mathrm{g} / \mathrm{dl}$ (Herman 2006). Kadar serum vitamin A dapat dikatakan normal apabila mencapai $20 \mu \mathrm{g} / \mathrm{dl}$ atau lebih (Sommer \& West 1998). Kurang Vitamin A (KVA) menyebabkan fungsi kekebalan tubuh menurun sehingga mempertinggi risiko anak terhadap penyakit infeksi (Almatsier 2005). Kelompok umur yang terutama mudah mengalami Kurang Vitamin A (KVA) adalah kelompok bayi usia 6-11 bulan dan kelompok anak balita usia 12-59 bulan (1-5 tahun). Kurang Vitamin A (KVA) dapat disebabkan oleh kurangnya asupan vitamin $A$ itu sendiri ataupun kurangnya ketersediaan provitamin $A$.

Wortel (Daucus carota L.) merupakan jenis sayuran yang terkenal sebagai sumber provitamin $A$ (karotenoid). Kandungan karotenoid wortel sebesar $2000 \mu \mathrm{g}$ RE/100 g BDD, jauh lebih tinggi dibandingkan tomat yang hanya $100 \mu \mathrm{g}$ RE/100 g BDD (Ball 1988). Selain kandungan karotenoid yang tinggi, produksi wortel di Indonesia pun cukup melimpah. Menurut data Badan Pusat Statistik (2007) produksi wortel di Indonesia mencapai 350170 ton dan sekitar $37 \%$ nya merupakan hasil produksi dari Provinsi Jawa Barat.

Telah banyak usaha dilakukan untuk menanggulangi masalah Kurang Vitamin A (KVA), diantaranya dengan suplementasi serta fortifikasi vitamin A pada produk pangan. Pemanfaatan serbuk wortel sebagai sumber provitamin A alami dalam pembuatan produk dapat dijadikan suatu alternatif usaha fortifikasi secara alami dalam upaya penanggulangan masalah Kurang Vitamin A (KVA) selain juga karena senyawa provitamin A alami jauh lebih aman dikonsumsi daripada vitamin A yang dibuat secara sintetis.

Pada saat ini mi telah digunakan sebagai salah satu bahan makanan alternatif pengganti nasi yang diterima baik oleh masyarakat. Data SUSENAS tahun 1999-2002 menunjukkan bahwa konsumsi mi mengalami peningkatan dari $3.1 \mathrm{~kg} / \mathrm{kap} /$ tahun menjadi $4.3 \mathrm{~kg} / \mathrm{kap} /$ tahun. Mi merupakan makanan yang disukai masyarakat luas, terutama anak-anak. Hasil penelitian yang dilakukan oleh Herliyanti et al. (2007) menunjukkan bahwa alasan ibu memberikan mi instan kepada anak balitanya adalah untuk menambah selera makan anak. World Food Programme (WFP) pun pernah menggunakan mi sebagai bahan makanan yang difortifikasi zat gizi mikro untuk intervensi pada anak usia $2-5$ tahun serta ibu hamil dan menyusui. Oleh karena itu, mi dapat dijadikan sebagai produk pangan yang mendukung upaya pe- nanggulangan masalah KVA di Indonesia, terutama untuk anak-anak. Melalui pemanfaatan wortel sebagai sumber B-karoten alami dalam pembuatan $\mathrm{mi}$ instan, mutu gizi mi yang selama ini sebagai sumber karbohidrat dapat ditingkatkan dan dijadikan pangan alternatif sumber vitamin $A$.

Tujuan umum dari penelitian ini adalah untuk mengkaji aplikasi serbuk wortel sebagai sumber B-karoten alami pada produk mi instan. Penelitian ini diharapkan dapat memberikan informasi kepada masyarat mengenai pemanfaatan serbuk wortel sebagai sumber B-karoten alami dalam pembuatan $\mathrm{mi}$ instan sebagai pangan alternatif sumber vitamin A. Penelitian ini juga dapat memberikan informasi pengembangan produk bagi industri makanan.

\section{METODE}

\section{Tempat, Waktu, \& Bahan Penelitian}

Penelitian dilaksanakan pada bulan April hingga Oktober 2009. Tempat yang digunakan untuk melakukan penelitian adalah Laboratorium Percobaan Pangan, Laboratorium Kimia dan Analisis Pangan serta Laboratorium Uji Organoleptik Departemen Gizi Masyarakat, Fakultas Ekologi Manusia, Institut Pertanian Bogor. Selain itu, untuk membuat serbuk wortel dan mi instan, digunakan Laboratorium Pilot Plan SEAFAST Center, Institut Pertanian Bogor. Analisis B-karoten dilakukan di Balai Besar Industri Agro (BBIA) Bogor.

Bahan utama yang digunakan dalam penelitian ini adalah wortel (Daucus carota L.). Wortel yang digunakan dalam pembuatan serbuk adalah wortel varietas lokal Cipanas yang diperoleh dari kelompok tani Pacet Segar di Cipanas, Kabupaten Cianjur. Wortel Cipanas merupakan tipe imperator, yaitu wortel yang memiliki umbi akar berukuran panjang dengan ujung meruncing. Wortel tipe imperator merupakan wortel yang cocok untuk tujuan pengeringan. Varietas ini dipilih karena ba-nyak diusahakan oleh petani Jawa Barat sehingga mudah diperoleh.

Bahan baku pembuatan mi antara lain tepung terigu, serbuk wortel, garam, $\mathrm{K}_{2} \mathrm{CO}_{3}, \mathrm{Na}_{2} \mathrm{CO}_{3}$, dan air. Selain bahan-bahan untuk pembuatan serbuk wortel dan $\mathrm{mi}$, juga digunakan bahan-bahan untuk analisis kimia.

\section{Tahapan Penelitian}

Penelitian diawali dengan pembuatan serbuk wortel. Proses pembuatan serbuk meliputi pencucian dan pengupasan wortel, pengirisan (slicing), perendaman dalam larutan Na-metabisulfit 0.25\% $(\mathrm{t}=15$ menit), penirisan, pengeringan dengan cabinet dryer (5-8 jam), dan penggilingan (60 mesh). Serbuk wortel kemudian dianalisis kandungan zat gizi dan sifat fisiknya. Kandungan zat gizi yang dianalisis meliputi analisis proksimat (kadar air menggunakan metode oven biasa, kadar abu menggunakan me- 
tode pengabuan kering, kadar protein menggunakan metode Mikrokjeldahl, kadar lemak menggunakan metode Soxhlet, dan kadar karbohidrat dengan metode by difference), serat pangan menggunakan metode enzimatis dan B-karoten menggunakan metode HPLC, sedangkan analisis sifat fisik yang diuji yaitu derajat warna dengan menggunakan alat chromameter Minolta CR-300.

Serbuk wortel didapatkan dengan cara mengeringkan wortel menggunakan cabinet dryer. Wortel dicuci dan dibersihkan serta dibuang bagian ujungnya. Wortel yang telah dibersihkan kemudian diiris tipis menggunakan slicer sehingga ukurannya menjadi lebih kecil, lalu direndam dalam larutan Na-metabisulfit $0.25 \%$ selama 15 menit. Proses perendaman ini bertujuan untuk mempertahankan warna dari serbuk wortel dan mempertahankan B-karoten selama penyimpanan (Rifnaldi 1997). Setelah direndam, wortel ditiriskan dan disebarkan secara merata di atas loyang untuk dikeringkan di dalam cabinet dryer. Suhu yang digunakan dalam pengeringan adalah sebesar $60-70^{\circ} \mathrm{C}$. Lama pengeringan wortel berkisar 5-6 jam. Irisan wortel dapat dikatakan kering jika sudah memiliki tekstur yang renyah dan mudah rapuh ketika diremas. Irisan wortel yang telah kering ini kemudian digiling untuk menghasilkan serbuk wortel berukuran 60 mesh.

Tahapan penelitian selanjutnya adalah formulasi mi dengan substitusi serbuk wortel. Perlakuan yang diberikan adalah substitusi serbuk wortel sebesar 0\% (F0), 10\% (F1), 15\% (F2), dan 20\% (F3). Perlakuan substitusi diberikan berdasarkan persentase serbuk wortel terhadap serbuk terigu. Penggunaan bahan lainnya seperti garam, $\mathrm{K}_{2} \mathrm{CO}_{3}, \mathrm{Na}_{2} \mathrm{CO}_{3}$, dan air yang digunakan pada setiap formula sama. Pembuatan mi menggunakan alat-alat seperti timbangan, pengaduk adonan, alat pengukus, alat pencetak mi, tray, dan cabinet dryer.

Mi yang dihasilkan kemudian diuji secara organoleptik (uji mutu hedonik dan hedonik) terhadap 30 panelis semi-terlatih. Uji mutu hedonik dan uji hedonik (kesukaan) dilakukan terhadap warna, aroma, rasa, dan tekstur menggunakan skala garis 1-9, dari sangat tidak baik sampai sangat baik untuk uji mutu hedonik dan dari sangat tidak suka sampai sangat suka pada uji hedonik. Pemilihan formula dilakukan berdasarkan hasil uji hedonik. Panelis dianggap menerima sampel bila nilai yang diberikan pada skala lebih dari lima. Formula terpilih kemudian dianalisis kandungan gizi meliputi analisis proksimat, serat pangan, dan B-karoten serta analisis sifat fisik meliputi uji derajat warna, waktu masak optimum, daya serap air, dan elongasi lalu diujikan kepada anak TK untuk mengetahui penerimaan. Penilaian dilakukan hanya untuk penerimaan keseluruhan dan nilai dikategorikan menjadi tiga, yaitu tidak suka (1), biasa (2) dan suka (3). Pengujian dilakukan pada mi wortel dan mi komersial sebagai pembanding.

\section{Pengolahan dan Analisis Data}

Rancangan percobaan yang digunakan untuk penelitian ini adalah Rancangan Acak Lengkap (RAL) dengan satu faktor perlakuan yaitu substitusi serbuk wortel. Peubah respon yang diamati adalah warna, aroma, tekstur, dan rasa dari mi wortel instan. Model matematisnya adalah sebagai berikut:

$$
Y i j=\mu+\tau i+\varepsilon i j
$$

Data sifat fisik dan kimia ditabulasi dan dirata-ratakan menggunakan Microsoft Excel 2007, sedangkan data hasil uji organoleptik dianalisis secara deskriptif menggunakan nilai rata-rata masingmasing perlakuan. Untuk mengetahui pengaruh jenis formula terhadap mutu hedonik dan tingkat kesukaan panelis terhadap mi wortel dilakukan analisis statistik Analysis of Variance (ANOVA), apabila hasil ini menunjukkan adanya perbedaan nyata diantara perlakuan maka dilakukan uji lanjutan Duncan Multiple Comparison Test. Uji penerimaan anak TK terhadap mi wortel jika dibandingkan dengan mi komersial dilakukan menggunakan uji Friedman.

\section{HASIL DAN PEMBAHASAN}

\section{Kandungan Zat Gizi dan Sifat Fisik Serbuk Wortel Kadar air}

Kadar air serbuk wortel yang dihasilkan adalah sebesar $5.96 \%$ bb. Nilai ini lebih rendah jika dibandingkan dengan kadar air hasil penelitian Rifnaldi (1997) yaitu sebesar 6.7-9.4\% bb. Menurut Sulaeman et al. (2001), penurunan kadar air dapat meningkatkan derajat kecerahan (nilai L, a dan b).

\section{Kadar abu}

Hasil analisis menunjukkan bahwa serbuk wortel memiliki kandungan abu sebesar $5.47 \%$ bk (5.26\% bb). Nilai ini lebih tinggi jika dibandingkan dengan hasil penelitian Rifnaldi (1997) yaitu sebesar 1.58-3.35\% bk. Penggunaan natrium metabisulfit $\left(\mathrm{Na}_{2} \mathrm{~S}_{2} \mathrm{O}_{5}\right)$ memengaruhi kadar abu serbuk wortel yang dihasilkan.

\section{Kadar protein}

Hasil analisis menunjukkan bahwa serbuk wortel memiliki kadar protein sebesar $8.15 \%$ bk (8.14\% bb). Wortel merupakan sayuran yang rendah kandungan proteinnya, yaitu sebesar $0.93 \%$ bb oleh karena itu nilai kadar protein pada serbuk wortel pun tergolong rendah.

\section{Kadar lemak}

Kadar lemak serbuk wortel berdasarkan hasil analisis adalah sebesar $2.50 \%$ bk $(2.37 \%$ bb). Seperti halnya kadar protein, kadar lemak pada serbuk wortel pun tergolong rendah. Hal ini juga sesuai dengan kandungan lemak yang rendah pada wortel, yaitu $0.24 \% \mathrm{bb}$. 


\section{Kadar karbohidrat}

Kadar karbohidrat pada serbuk wortel dihitung dengan penentuan karbohidrat secara kasar menggunakan metode by difference. Hasil analisis menunjukkan bahwa kadar karbohidrat serbuk wortel yang dihasilkan adalah sebesar $71.96 \%$ bk.

\section{Kadar serat pangan}

Kadar serat pangan serbuk wortel yang dihasilkan tergolong tinggi. Hasil analisis menunjukkan bahwa kadar serat pangan serbuk wortel sebesar $33.74 \%$ bk (31.55\% bb) yaitu terdiri atas $28.39 \%$ bk $(26.53 \% \mathrm{bb})$ serat tidak larut, dan $5.35 \%$ bk $(5.02 \%$ bb) serat larut. Hasil tersebut menunjukkan bahwa kandungan serat tidak larut pada serbuk wortel lebih tinggi dibandingkan serat larut. Menurut Almatsier (2005), jenis serat tidak larut yang terdapat pada wortel adalah selulosa dan lignin.

\section{Kadar B-Karoten}

Hasil analisis B-karoten dengan metode HPLC menunjukkan bahwa kandungan B-karoten pada serbuk wortel adalah sebesar $20550 \mu \mathrm{g} / 100 \mathrm{~g}$. Nilai ini tergolong lebih rendah jika dibandingkan dengan kandungan $B$-karoten pada keripik wortel yaitu berada pada kisaran 25196-43 $804 \mu \mathrm{g}$ B-karoten/100 $\mathrm{g}$ keripik wortel (Sulaeman et al. 2001). Jika dikonversi ke dalam vitamin A, maka serbuk wortel mengandung vitamin A sebesar 3425 RE atau 1712.5 RAE.

\section{Rendemen}

Rendemen merupakan persentase perbandingan antara berat serbuk wortel yang dihasilkan dengan berat bersih wortel. Nilai rendemen serbuk wortel adalah sebesar $8.3 \%$. Nilai rendemen serbuk wortel pada penelitian ini lebih tinggi daripada serbuk wortel.

\section{Derajat warna}

Nilai L, a, dan b serbuk wortel berturutturut adalah sebesar 62.58; 20.70; dan 27.85. Nilai a/b serbuk yang dihasilkan adalah sebesar 0.74 . Nilai $\mathrm{Hue}^{\circ}$ dari serbuk wortel yang dihasilkan yaitu sebesar 53.38. Nilai Hue ${ }^{\circ}$ pada kisaran 18-54 mengindikasikan bahwa serbuk wortel dikategorikan berada pada derajat warna red.

\section{Pembuatan Mi Wortel Instan}

Pembuatan mi wortel diawali dengan formulasi mi. Formulasi awal dilakukan dengan metode trial and error untuk mencari perbandingan komposisi adonan sehingga didapat formula standar mi. Perlakuan substitusi minimum serbuk wortel ditentukan berdasarkan 15\% kecukupan Vitamin A untuk anak usia 4-5 tahun. Tingkat substitusi yang digunakan dalam pembuatan mi wortel instan terdiri dari tiga taraf, yaitu $10 \%$, 15\%, dan $20 \%$. Komposisi adonan mi setiap formula dapat dilihat pada Tabel 1.

Pencampuran adonan merupakan tahapan pertama yang dilakukan dalam proses pembuatan mi wortel instan. Tahapan selanjutnya adalah pembentukan lempengan menggunakan mesin pelempeng (roll press). Pada awalnya adonan yang keluar dari mesin bersifat rapuh dan kasar, setelah dilewatkan secara berulang-ulang diantara roll, adonan semakin menyatu dan kompak sehingga terbentuk lembaran mi. Pencetakan mi (slitting) merupakan tahapan dimana lembaran adonan dipotong menjadi untaian mi. Lembaran mi yang tipis selanjutnya dicetak menjadi untaian mi menggunakan roller slitter.

Mi yang telah dipotong dan dibentuk kemudian dikukus. Pengukusan dilakukan selama 10 menit pada suhu $95-100^{\circ} \mathrm{C}$. Tahapan selanjutnya pada proses pembuatan mi wortel instan adalah proses pengeringan menggunakan metode pengeringan. Pengeringan dilakukan pada suhu $60-70^{\circ} \mathrm{C}$ selama 1-1.5 jam. Pengeringan dianggap cukup jika mi mudah dipatahkan dan tidak menempel lagi pada tray.

\section{Karakteristik Organoleptik Mi Wortel Instan Mutu hedonik}

Warna. Nilai rata-rata penilaian organoleptik terhadap parameter mutu warna mi berkisar dari 2.17-8.11 atau berada pada kisaran sangat pucat sampai sangat jingga. Warna jingga pada mi wortel disebabkan oleh kandungan karotenoid yang terkandung di dalam serbuk wortel. Nilai rata-rata mutu warna tertinggi adalah pada mi formula F3 (8.11) dan berdasarkan uji lanjut Duncan nilai ini berbeda nyata dengan nilai rata-rata mutu warna mi formula F0, F1, dan F2. Nilai rata-rata mutu warna terendah (2.17) adalah pada mi formula F0.

Tabel 1. Komposisi Adonan Mi

\begin{tabular}{lcccc}
\hline \multicolumn{1}{c}{ Bahan } & \multicolumn{4}{c}{ Jumlah (g) } \\
\cline { 2 - 5 } & $\begin{array}{c}\text { Kontrol } \\
\text { (F0) }\end{array}$ & $\begin{array}{c}\text { Substitusi 10\% } \\
\text { (F1) }\end{array}$ & $\begin{array}{c}\text { Substitusi 15\% } \\
\text { (F2) }\end{array}$ & $\begin{array}{c}\text { Substitusi 20\% } \\
\text { (F3) }\end{array}$ \\
\hline Tepung terigu & 100 & 90 & 85 & 80 \\
Serbuk wortel & - & 10 & 15 & 20 \\
Garam & 1.5 & 1.5 & 1.5 & 1.5 \\
$\mathrm{~K}_{2} \mathrm{CO}_{3}$ & 0.2 & 0.2 & 0.2 & 0.2 \\
$\mathrm{Na}_{2} \mathrm{CO}_{3}$ & 0.2 & 0.2 & 0.2 & 0.2 \\
Air & 38 & 38 & 38 & 38 \\
Perkiraan kadar Vit. A (RE)/100 g & 0.0 & 252 & 378 & 504 \\
Perkiraan kadar Vit. A (RAE)/100 g & 0.0 & 126 & 189 & 252 \\
\hline
\end{tabular}


Aroma. Hasil penilaian organoleptik terhadap mutu aroma mi menunjukkan bahwa nilai rata-rata mutu aroma mi adalah 2.85-6.89 atau berada pada kisaran sangat tidak beraroma sampai agak beraroma wortel. Peningkatan tingkat substitusi serbuk wortel menyebabkan aroma wortel yang dihasilkan serbuk wortel semakin tercium. Nilai rata-rata mutu aroma tertinggi (6.89) adalah pada mi formula F3. Nilai rata-rata mutu aroma terendah (2.85) adalah pada mi formula F0. Hasil uji lanjut Duncan menunjukkan bahwa setiap formula memiliki perbedaan yang nyata.

Rasa. Penilaian organoleptik terhadap mutu rasa mi terdiri atas rasa asin dan rasa manis yang terdapat pada mi. Hasil penilaian organoleptik terhadap parameter mutu rasa mi berada pada nilai rata-rata 1.20-6.51 untuk rasa manis atau berada pada kisaran amat sangat tidak manis sampai agak manis, sedangkan untuk rasa asin berada pada nilai rata-rata 2.93-4.10 atau berada pada kisaran sangat tidak terasa sampai agak tidak terasa. Hal ini menunjukkan bahwa rasa manis mendominasi mi wortel dibandingkan rasa asin.

Nilai rata-rata mutu rasa manis tertinggi (6.51) adalah pada mi formula F3 dan nilai rata-rata mutu rasa manis terendah adalah pada mi formula F0. Hasil uji lanjut Duncan menunjukkan bahwa keempat formula mi berbeda nyata. Pada rasa asin, nilai rata-rata tertinggi (4.10) adalah pada mi formula FO dan berdasarkan uji lanjut Duncan, nilai ini berbeda nyata $(\alpha<0.05)$ dengan mi formula $F 1, F 2$, dan F3. Nilai rata-rata mutu rasa asin terendah adalah pada mi formula F3 yang berbeda nyata dengan formula F0, F1, dan F2.

Tekstur. Hasil penilaian organoleptik terhadap mutu tekstur mi memiliki nilai rata-rata 1.48-7.64 atau berada pada kisaran amat sangat tidak elastis sampai elastis. Nilai rata-rata mutu tekstur tertinggi (7.64) adalah pada mi formula F0 dan berdasarkan uji lanjut Duncan, nilai ini berbeda nyata $(\alpha<0.05)$ dengan nilai rata-rata mi formula F1, F2, dan F3. Nilai rata-rata terendah (1.48) adalah pada mi formula F3, nilai ini juga berbeda nyata dengan ketiga formula lainnya. Nilai rata-rata mutu tekstur mi menunjukkan bahwa semakin tinggi substitusi serbuk wortel maka mutu mi semakin rendah (tidak elastis). Hal ini disebabkan oleh kandungan serat yang tinggi (33.7\%) pada serbuk wortel.

\section{Hedonik (kesukaan)}

Pada uji hedonik, mi disajikan tanpa kuah dan berkuah. Hasil sidik ragam menunjukkan tingkat kesukaan panelis terhadap warna, aroma, dan rasa mi tanpa kuah memiliki perbedaan nyata $(\alpha<0.05)$, namun pada mi berkuah tidak berbeda nyata $(\alpha>0.05)$. Tingkat kesukaan panelis terhadap tekstur mi tanpa kuah maupun berkuah tidak berbeda nyata ( $\alpha>0.05)$. Data tingkat kesukaan panelis terhadap warna, aroma, rasa, dan tekstur mi disajikan pada Tabel 2, sedangkan data persentase penerimaan panelis terhadap mi dapat dilihat pada Tabel 3.

Warna. Nilai rata-rata tertinggi tingkat kesukaan panelis terhadap warna mi adalah pada mi formula $\mathrm{F} 1$ baik pada mi tanpa kuah maupun mi berkuah, dengan nilai rata-rata masing-masing sebesar 7.67 dan 7.63 atau berada pada kisaran suka. Mi formula F0 memiliki nilai rata-rata terendah pada mi tanpa kuah (6.23) dan mi yang diberi kuah (6.47) atau berada pada kisaran agak suka (Tabel 2 ).

Persentase panelis yang dapat menerima warna mi kontrol (F0) lebih rendah dibandingkan persentase penerimaan panelis terhadap warna mi dengan perlakuan substitusi serbuk wortel (F1, F2, dan F3). Persentase panelis yang dapat menerima warna mi wortel instan adalah $100 \%$.

Aroma. Aroma mi formula F0 tanpa kuah memperoleh nilai rata-rata tingkat kesukaan tertinggi (6.13), yaitu pada kisaran agak suka, sedangkan aroma mi formula F2 dan F3 tanpa kuah memperoleh nilai rata-rata tingkat kesukaan terendah (5.10), yaitu berada pada kisaran biasa. Pada mi berkuah, aroma mi formula F0 memperoleh nilai rata-rata tingkat kesukaan tertinggi (6.47), sedangkan aroma mi formula F3 memperoleh nilai ratarata tingkat kesukaan terendah (5.93). Persentase panelis yang dapat menerima aroma mi, baik yang diberi kuah maupun tanpa kuah berada pada kisaran 50\% hingga 90\%, sedangkan panelis yang dapat menerima aroma mi wortel tanpa kuah berada pada kisaran 50-53\%. Penerimaan panelis terhadap aroma mi, baik mi kontrol maupun mi substitusi serbuk wortel, meningkat setelah mi diberi kuah. Mi formula F0 yang diberi kuah memperoleh nilai persentase penerimaan aroma tertinggi (90\%), sedangkan mi formula F1 memperoleh nilai persentase penerimaan terendah (70\%).

Rasa. Pada mi tanpa kuah, rasa mi formula F0 memperoleh nilai rata-rata tingkat kesukaan tertinggi (5.27), sedangkan mi formula F3 memperoleh

Tabel 2. Data Tingkat Kesukaan Panelis terhadap Warna, Aroma, Rasa, dan Tekstur Mi

\begin{tabular}{|c|c|c|c|c|c|c|c|c|}
\hline \multirow{2}{*}{ Parameter (\%) } & \multicolumn{4}{|c|}{ Tanpa Kuah } & \multicolumn{4}{|c|}{ Kuah } \\
\hline & F0 & F1 & F2 & F3 & F0 & F1 & F2 & F3 \\
\hline Warna & 6.23 & 7.67 & 7.47 & 7.30 & 6.47 & 7.63 & 7.53 & 7.33 \\
\hline Aroma & 6.13 & 5.40 & 5.10 & 5.10 & 6.47 & 6.03 & 6.17 & 5.93 \\
\hline Rasa & 5.27 & 5.20 & 4.87 & 4.63 & 6.27 & 6.23 & 6.13 & 6.17 \\
\hline Tekstur & 6.07 & 5.87 & 5.47 & 5.33 & 6.13 & 6.23 & 6.20 & 6.17 \\
\hline Keseluruhan & 6.30 & 6.70 & 6.23 & 5.50 & 6.60 & 6.83 & 6.57 & 5.73 \\
\hline
\end{tabular}


Tabel 3.Tingkat Penerimaan Panelis terhadap Mi

\begin{tabular}{|c|c|c|c|c|c|c|c|c|}
\hline \multirow[b]{2}{*}{ Parameter (\%) } & \multicolumn{4}{|c|}{ Tanpa Kuah } & \multicolumn{4}{|c|}{ Kuah } \\
\hline & F0 & F1 & $\mathrm{F} 2$ & F3 & F0 & F1 & F2 & F3 \\
\hline Warna & 77 & 100 & 100 & 100 & 87 & 100 & 100 & 100 \\
\hline Aroma & 77 & 53 & 50 & 50 & 90 & 70 & 77 & 73 \\
\hline Rasa & 53 & 53 & 46 & 40 & 87 & 83 & 77 & 77 \\
\hline Tekstur & 73 & 60 & 60 & 63 & 77 & 77 & 83 & 83 \\
\hline Keseluruhan & 77 & 90 & 90 & 60 & 97 & 97 & 97 & 67 \\
\hline
\end{tabular}

nilai rata-rata tingkat kesukaan terendah (4.63). Pada mi berkuah, rasa mi formula F0 memperoleh nilai rata-rata tingkat kesukaan tertinggi (6.27), sedangkan rasa mi formula $\mathrm{F} 3$ memperoleh nilai ratarata tingkat kesukaan terendah (6.17).

Rasa mi formula F3 tanpa kuah memperoleh nilai persentase penerimaan terendah (40\%), sedangkan rasa mi formula F0 dan F1 tanpa kuah memperoleh nilai persentase penerimaan tertinggi (53\%). Pada mi kuah, rasa mi formula F0 memperoleh nilai persentase penerimaan tertinggi (87\%), sedangkan rasa mi formula $\mathrm{F} 3$ memperoleh nilai persentase penerimaan terendah $(77 \%)$.

Tekstur. Tekstur mi tanpa kuah formula F0 dan mi berkuah formula F1 memperoleh nilai ratarata tingkat kesukaan tertinggi, yaitu masing-masing sebesar 6.07 dan 6.23. Nilai rata-rata tingkat kesukaan terendah diperoleh mi formula F3 tanpa kuah (5.33) dan mi berkuah formula F0 (6.13).

Persentase panelis yang dapat menerima tekstur mi berada pada kisaran $60 \%$ hingga $73 \%$ untuk mi tanpa kuah dan $77 \%$ hingga $83 \%$ untuk mi berkuah. Pada mi tanpa kuah, persentase penerimaan tertinggi diperoleh mi formula F0, sedangkan pada mi berkuah, persentase penerimaan tertinggi diperoleh mi formula F2 dan F3.

Keseluruhan. Mi formula F1 tanpa kuah secara keseluruhan memperoleh nilai rata-rata tingkat kesukaan tertinggi (6.70), sedangkan mi formula F3 tanpa kuah memperoleh nilai rata-rata tingkat kesukaan terendah (5.50). Pada mi berkuah, formula F1 secara keseluruhan memperoleh nilai rata-rata tingkat kesukaan tertinggi (6.83), sedangkan mi formula F3 secara keseluruhan memperoleh nilai rata-rata terendah (5.73).

Secara keseluruhan mi formula F3 (tanpa kuah maupun berkuah) memperoleh nilai persentase penerimaan terendah, sedangkan mi formula F1 dan F2 (tanpa kuah maupun berkuah) memperoleh nilai persentase penerimaan keseluruhan tertinggi, yaitu sebesar $90 \%$ untuk mi tanpa kuah dan $97 \%$ untuk mi berkuah. Hal ini menunjukkan bahwa mi formula F1 dan F2 merupakan formula yang paling disukai panelis. Formula F2 merupakan formula terpilih yang digunakan dalam tahapan penelitian selanjutnya karena mengandung serbuk wortel dalam jumlah yang lebih tinggi dibandingkan F1 dengan persentase penerimaan yang lebih tinggi.

\section{Kandungan Zat Gizi dan Sifat Fisik Mi Wortel Kadar air}

Kadar air mi yang dihasilkan sebesar 7.75\%. Nilai ini lebih rendah jika dibandingkan dengan kandungan air mi wortel hasil penelitian Prananto (2003), yaitu berkisar antara 8.10-8.68\%. Syarat mutu mi instan menurut SNI 01-3551-2000 untuk kadar air dengan teknik pengeringan, kadar air maksimal $14.5 \%$. Berdasarkan persyaratan tersebut dapat dikatakan bahwa kadar air mi wortel instan telah memenuhi SNI.

\section{Kadar abu}

Kadar abu mi wortel instan hasil analisis adalah sebesar $1.59 \%$ bk. Nilai ini berada pada kisaran hasil penelitian Prananto (2003), mi wortel yang dihasilkan memiliki kadar abu 1.55-1.82\% bk. Kadar abu mi wortel telah sesuai dengan SNI 01-2974-1992 yang menyatakan bahwa batas maksimal kandungan abu dalam mi yang dikeringkan sebesar $3 \%$.

\section{Kadar protein}

Hasil analisis menunjukkan kadar protein mi wortel instan sebesar $12.82 \%$ bk (12.81\% bb). Nilai tersebut lebih tinggi jika dibandingkan dengan mi wortel hasil penelitian Prananto (2003), yaitu $11.10-11.60 \%$ bk. Syarat mutu mi instan menurut SNI 01-3551-2000, kadar protein mi yang dibuat dengan berbahan dasar terigu minimal mengandung $8.0 \%$ bb protein. Oleh karena itu dapat dikatakan bahwa kadar protein mi wortel instan sudah memenuhi SNI mi instan.

\section{Kadar lemak}

Hasil analisis lemak menunjukkan kadar lemak mi wortel instan sebesar $1.41 \%$ bk. Nilai ini lebih tinggi jika dibandingkan dengan kadar lemak mi wortel hasil penelitian Prananto (2003), yaitu berkisar antara $0.61-0.83 \%$ bk.

\section{Kadar karbohidrat}

Kadar karbohidrat mi wortel instan dihitung menggunakan metode by difference. Kadar karbohidrat mi wortel instan adalah sebesar $76.43 \%$ bk. Nilai ini sedikit lebih rendah jika dibandingkan dengan kadar karbohidrat mi instan dengan penambahan Red Palm Oil hasil penelitian Rucita (2010), yaitu sebesar $74.49 \%$ (bk). 


\section{Kadar serat pangan}

Kadar serat pangan mi wortel instan adalah sebesar $4.37 \%$ bk. Nilai ini lebih tinggi jika dibandingkan dengan kadar serat pangan pada mi sorgum, yaitu sebesar $2.86 \%$ bk (Indriani 2005). Kadar serat yang cukup tinggi pada mi wortel memengaruhi tekstur mi yang dihasilkan.

\section{Kadar B-Karoten}

Hasil analisis B-karoten dengan metode HPLC menunjukkan bahwa kandungan B-karoten pada mi wortel terpilih adalah sebesar $2390 \mu \mathrm{g} / 100 \mathrm{~g}$. Jika dikonversi, nilai tersebut setara dengan $398 \mathrm{RE}$ atau 199 RAE vitamin A. Mi wortel dapat memenuhi lebih dari 15\% AKG untuk vitamin A, sehingga dapat dikatakan sebagai sumber vitamin A bagi anak usia 4-5 tahun. Perhitungan tingkat kecukupan vitamin A anak usia 4-5 tahun per takaran saji mi dapat dilihat pada Tabel 4.

Kehilangan B-karoten pada proses pengolahan mi wortel instan adalah sebesar $17.30 \%$. Nilai kehilangan tersebut berada pada kisaran kehilangan B-karoten pro-ses pengolahan mi kering wortel hasil penelitian Prananto (2003), yaitu 7.5-21.77\%.

\section{Derajat warna}

Nilai L, a, dan b mi wortel berturut-turut adalah sebesar 46.03, 2.68, dan 14.78. Nilai ini lebih rendah jika dibandingkan dengan hasil derajat warna pada serbuk wortel $(L=62.58$; $a=20.70$; dan $b=27.85$ ). Nilai a/b mi yang dihasilkan adalah sebesar 0.18. Nilai Hue ${ }^{\circ}$ dari mi wortel yang dihasilkan yaitu sebesar 79.72. Nilai Hue ${ }^{\circ}$ pada kisaran 54-90 mengindikasikan bahwa mi wortel dikategorikan berada pada derajat warna red yellow. Nilai Hue ${ }^{\circ}$ pada mi wortel lebih tinggi dibandingkan serbuk wortel, hal ini sesuai dengan hasil penelitian Sulaeman et al. (2001) dan Skrede et al. (1997) yang menunjukkan adanya korelasi negatif antara nilai Hue ${ }^{\circ}$ dengan kandungan B-karoten. Mi wortel memiliki kandungan B-karoten yang lebih rendah (23.9 ppm) dibandingkan dengan serbuk wortel (205.5 ppm).

\section{Waktu masak optimum}

Waktu masak optimum adalah waktu yang dibutuhkan mi untuk kembali mengabsorbsi air sehingga teksturnya menjadi kenyal dan elastis. Hasil pengukuran menunjukkan waktu masak optimum mi wortel selama 3.5 menit. Jika mi terlalu matang (overcooked), maka mi dapat menjadi lengket dan mudah hancur. Sebaliknya jika mi belum matang benar, bagian tengah mi masih terasa keras saat dikunyah.

\section{Daya serap air}

Daya serap air merupakan kemampuan mi untuk menyerap air secara maksimal. Daya serap air mi wortel adalah sebesar $143.89 \%$ bk. Nilai ini lebih tinggi jika dibandingkan dengan mi terigu yang memiliki daya serap air sebesar $138.60 \%$ bk (Indriani 2005).

\section{Elongasi}

Elongasi menunjukkan persen pertambahan panjang maksimum mi yang mengalami tarikan sebelum putus. Persen elongasi mi wortel berdasarkan hasil uji menggunakan metode Rheoner adalah sebesar 162.22\%. Nilai ini lebih rendah jika dibandingkan dengan nilai elongasi mi komersial, yaitu $381.96 \%$.

\section{Penerimaan mi wortel pada anak TK}

Uji penerimaan mi wortel dilakukan terhadap anak TK usia 4-5 tahun sebagai panelis. Panelis diminta untuk memberi penilaian terhadap mi wortel dan mi komersial. Tabel 5 merupakan rekapitulasi hasil uji penerimaan mi pada anak TK (usia 4-5 tahun).

Pada saat melakukan uji daya terima, mi wortel dan mi komersial disajikan dengan kuah yang biasa digunakan pada mi komersial. Pada Tabel 5 dapat dilihat bahwa persentase panelis yang menyukai mi wortel (86.67\%) lebih tinggi dibandingkan mi komersial (83.33\%). Berdasarkan hasil uji Friedman, pada taraf signifikansi 5\%, tidak terdapat perbedaan yang nyata antara tingkat kesukaan panelis terhadap mi wortel dengan mi komersial. Nilai persentase tingkat kesukaan panelis dan hasil uji Friedman menunjukkan bahwa mi wortel dapat diterima oleh panelis, yaitu anak TK (usia 4-5 tahun).

\section{KESIMPULAN}

Serbuk wortel didapatkan dengan cara mengeringkan wortel menggunakan cabinet dryer pada suhu $60-70^{\circ} \mathrm{C}$ selama 5-6 jam, dengan nilai rendemen serbuk sebesar $8.3 \%$. Kandungan zat gizi serbuk wortel adalah: kadar air 5.96\% bb, kadar abu 5.26\% bb $(5.47 \%$ bk), kadar protein $8.14 \%$ bb (8.15\% bk), kadar lemak 2.37\% bb (2.50\% bk), kadar karbohidrat $78.27 \%$ bb $(83.88 \%$ bk), dan kadar serat pangan $31.55 \%$ bb (33.74\% bk). Serbuk wortel memiliki kandungan B-karoten $20550 \mu g / 100$ g. Nilai L, a, dan b serbuk wortel berturut-turut adalah sebesar 62.58 , 20.70, dan 27.85 dengan nilai a/b sebesar 0.74 , dan nilai Hue ${ }^{\circ}$ sebesar 53.38 (red). Secara keseluruhan, nilai tertinggi persentase penerimaan panelis ada-

Tabel 4. Tingkat Kecukupan Vitamin A Anak Usia 4-5 Tahun yang Dapat Dipenuhi Per Takaran Saji Mi Wortel Instan

\begin{tabular}{|c|c|c|c|c|}
\hline Satuan & $\begin{array}{c}\text { Vitamin A per } \\
100 \mathrm{~g} \mathrm{Mi}\end{array}$ & $\begin{array}{c}\text { Vitamin A per } \\
\text { Takaran Saji (50 g) }\end{array}$ & $\begin{array}{c}\text { Kecukupan } \\
\text { Vitamin A }\end{array}$ & $\begin{array}{c}\text { Tingkat Kecukupan per } \\
\text { Takaran Saji (\%) }\end{array}$ \\
\hline RE & 398 & 199 & 450 & 44.22 \\
\hline RAE & 199 & 99.5 & 400 & 24.90 \\
\hline
\end{tabular}


Tabel 5. Rekapitulasi Hasil Uji Penerimaan Mi

\begin{tabular}{lcccc}
\hline \multirow{3}{*}{ Penerimaan } & \multicolumn{4}{c}{ Jenis Mi } \\
\cline { 2 - 5 } & $\mathbf{n}$ & MiWortel & $\mathbf{n}$ & Mi Komersial \\
\cline { 2 - 5 } & 26 & 86.67 & 25 & 83.33 \\
\hline Suka & 1 & 3.33 & 1 & 3.33 \\
Biasa & 3 & 10.00 & 4 & 13.33 \\
Tidak suka & 3 & & \\
\hline
\end{tabular}

lah terhadap formula F1 (tingkat substitusi serbuk wortel 10\%) yaitu sebesar $90 \%$ untuk mi tanpa kuah, dan F2 (tingkat substitusi serbuk wortel 15\%) yaitu sebesar $97 \%$ untuk mi berkuah. Fomula terpilih yang digunakan pada tahapan penelitian selanjutnya adalah formula F2. Kandungan zat gizi formula mi wortel instan terpilih (F2) adalah kadar air sebesar $7.75 \%$ bb, kadar abu $1.51 \%$ bb $(1.59 \%$ bk), kadar protein $12.81 \%$ bb (12.82\% bk), kadar lemak $1.30 \%$ bb $(1.41 \%$ bk), kadar karbohidrat $76.63 \%$ bb $(84.18 \%$ bk), dan kadar serat pangan $4.11 \%$ bb $(4.37 \%$ bk). Kandungan B-karoten mi wortel sebesar $2390 \mu \mathrm{g} / 100 \mathrm{~g}$. Adapun sifat fisik mi wortel menunjukkan nilai $L$, $a$, dan $b$ berturut-turut adalah sebesar 46.03, 2.68, dan 14.78 dengan nilai a/b sebesar 0.18 dan nilai Hue ${ }^{\circ}$ sebesar 79.72 (red yellow). Waktu masak optimum adalah 3.5 menit, daya serap air sebesar $143.89 \%$ bk dan persen elo-ngasi mi sebesar 162.22\%. Persentase anak TK (usia 4-5 tahun) yang menyukai mi wortel formula F2 sebesar $86.67 \%$, tidak berbeda nyata dengan mi komersial yaitu sebesar $83.33 \%$ pada taraf signifikansi $5 \%$.

Penelitian lanjutan mengenai pengaruh lama penyimpanan terhadap kandungan zat gizi, khususnya B-karoten, perlu dilakukan. Selain untuk mengetahui daya simpan mi wortel, hal ini dibutuhkan untuk mengetahui seberapa besar penurunan kandungan B-karoten dan zat gizi lainnya selama penyimpanan.

Pengaruh konsumsi mi wortel terhadap kadar serum vitamin A pun dibutuhkan untuk mengetahui aktifitas provitamin A (B-karoten) di dalam tubuh. $\mathrm{Hal}$ ini terkait dengan faktor yang memengaruhi penyerapan dan penggunaan B-karoten dalam tubuh.

\section{DAFTAR PUSTAKA}

Almatsier S. 2005. Prinsip Dasar Ilmu Gizi. Edisi ke-5. Gramedia Pustaka Utama, Jakarta.

Ball GFM. 1988. Fat-Soluble Vitamin Assays in Food Analysis. Elsevier Science Publ. Co.Inc., USA.

BPS. 2007. Statistik Years Book of Indonesia. BPS, Jakarta.

Herliyanti MP, Marbun R, Primidiawati S, \& Suciati L. 2007. Pola perilaku makan mi instan pada anak balita di TK Teratai Pasar Minggu Jakarta dan siswa SMU 3 Bekasi. Sanitas. J Teknologi dan Seni Kesehatan, 1, 1-118.
Herman S. 2006. Masalah kurang vitamin A (KVA) dan prospek penanggulangannya. Media Penelitian dan Pengembangan Kesehatan, 18(4).

Indriani S. 2005. Desain Proses Pembuatan dan Formulasi Mi Instan dari Campuran Tepung Shorgum (Shorgum bicolor L.), Pati Jagung dan Gluten Terigu. [Skripsi]. Fakultas Teknologi Pertanian. Institut Pertanian Bogor, Bogor.

Maqsood M, Dancheck B, Gamble MV, Palafox NA, Ricks MO, Briand K, \& Semba RD. 2004. Vitamin A deficiency and inflammatory markers among preschool children in The Republic of The Marshall Islands. JN 3, 21.

Prananto F. 2003. Peningkatan Mutu Gizi Mie Kering dengan Pemanfaatan Wortel sebagai Sumber B-Karoten Alami. [Skripsi]. Fakultas Pertanian, Institut Pertanian Bogor, Bogor.

Rifnaldi. 1997. Mempelajari Pengaruh Penambahan Bahan Pengisi dan Natirum-bisulfit pada Pembuatan Tepung Wortel. [Skripsi]. Fakultas Teknologi Pertanian, Institut Pertanian Bogor, Bogor.

Rucita N. 2010. Pemanfaatan Red Palm Oil (RPO) sebagai Sumber Provitamin A Alami pada Produk $\mathrm{Mi}$ Instan untuk Anak Balita. [Skripsi]. Fakultas Ekologi Manusia, Institut Pertanian Bogor, Bogor.

Sommer A \& West KP. 1998. Vitamin A deficiency: health, survival and vision. Book Review. Am. J Epidemiol 147, 1175-1176.

Skrede G, Nilsson A, Baardseth P, Rosenfeld HJ, Enersen G, \& Slinde E. 1997. Evaluation of carrot varieties for production of deep fried carrot chips. Food Res Intern, 30, 73-81.

Sulaeman A, Laurie K, Steve LT, David WG, \& Judy AD. 2001. Carotenoid content, physicochemical and sensory qualities of deep fried carrot chips as a-ffected by dehydration/rehydration, antioxidant and fermentation. J Agric Food Chem, 49,3253-3261.

SUSENAS [Survei Sosial Ekonomi Nasional]. 2002. Perkembangan konsumsi pangan periode sebelum, masa dan pasca krisis ekonomi. Media Penyalur Informasi Pangan dan Gizi, 15(2).

West KP. 2002. Extent of vitamin A deficiency among preschool children and women of reproductive age. JN 132, 2857S-2866S. 
